\title{
Post-Keynesian economics - how to move forward
}

\author{
Engelbert Stockhammer and Paul Ramskogler*
}

\begin{abstract}
Post-Keynesian Economics (PKE) is at the crossroads. Post-Keynesians (PKs) have become effectively marginalized; the academic climate at universities has become more hostile to survival and the mainstream has become more diverse internally. Moreover, a heterodox camp of diverse groups of non-mainstream economists is forming. The debate on the future of PKE has so far focussed on the relation to the mainstream. This paper argues that this is, in fact, not an important issue for the future of PKE. The debate has so far strangely overlooked the dialectics between academic hegemony and economic (and social) stability. In times of crisis the dominant economic paradigm becomes vulnerable. The important question is, whether PKE offers useful explanations of ongoing socio-economic transformations. PKE has generated valuable insights on core areas such as monetary macroeconomics and medium-term growth theory, but it offers little on important real world phenomena like the globalisation of production and social issues like precarisation and the polarization of income distribution or ecological challenges like climate change. It is these issues that will decide the future of PKE.
\end{abstract}

$J E L$ classifications: $B 20, B 50, B 59, E_{I 2}$

Keywords: post-Keynesian economics, mainstream economics, heterodox economics, neo-liberalism

* Vienna University of Economics and Business. An earlier version of the paper has been presented at the conference "Macroeconomic Policies on Shaky Foundations - Whither Mainstream Economics?", Berlin, November 2008. The authors are grateful to the participants at the discussion there as well as to Fred Lee, John E. King and an anonymous referee for helpful comments. All remaining errors are the authors'.

Correspondence Address:

Engelbert Stockhammer, Vienna University of Economics and Business, Augasse 2-6, A Iogo Vienna, Austria, e-mail: engelbert.stockhammer@wu-wien.ac.at.

Received I8 December 2008, accepted 30 April 2009

(C) INTERVENTION 6 (2), 2009, 227-246 


\section{Introduction}

Post-Keynesian Economics (PKE) is at the crossroads. While post-Keynesians (PKs) have established their niche, they have become marginalized and are effectively ignored by the mainstream. At the same time new challenges have arisen. The academic climate at universities has become more hostile to survival with research assessments and journal ratings degrading their work. The mainstream has become more diverse internally. A heterodox camp of diverse groups of non-mainstream economists is forming.

How should PKE deal with these challenges? Fontana and Gerrard (2006) argue that many PKs lack sufficient knowledge of mainstream economics and that it is vital that PKs enter a dialogue with the mainstream. Addressing the question of the relation of the mainstream and heterodox economics more generally, Colander et al. (2004) have argued that the mainstream is in a process of transition to a new orthodoxy that is based on a post-Walrasian revolution in microeconomics. The new mainstream would be open to consider all arguments provided they are presented in a formalized way. These claims have been critiqued by Dutt (2005) and King (2008) who question that post-Walrasian microeconomics is becoming a new mainstream and argue that macroeconomics has become more rather than less orthodox.

This paper argues that the debate on how PKE relates to the mainstream is, in fact, not an important issue for the future of PKE. The debate has so far strangely overlooked the dialectics between academic hegemony and economic (and social) stability. In times of crisis the dominant economic paradigm becomes vulnerable, which opens possibilities for heterodox streams. The hegemony of the mainstream will thus crucially depend on the viability of the socio-economic regime. In order to formulate a strategy for PKE to move forward the paper investigates changes in the regime of accumulation, developments within the mainstream and achievements and shortcomings of PKE.

Rather than clarifying PKE's position with respect to the mainstream, the important issue is, whether PKE offers useful explanations of ongoing socio-economic transformations. Here our assessment will be mixed. To be clear, our criticism is a friendly one, coming from within. We are working in this paradigm ourselves and strongly believe that it is superior to the mainstream in terms of realism of assumptions and the relevance of the analysis. Based on the principle of effective demand and a focus on uncertainty and income distribution it has generated insights on core areas such as monetary macroeconomics and medium-term growth theory. Thus it provides analyses and answers for many of the most pressing economic problems such as financial crises and mass unemployment. However, there is no reason for PKs to rest on their laurels. Exactly because PKE is so fruitful and promising it is a real pity that there is little PKE has to say on important real world issues that range from supply-side phenomena like the increasing use of ICT and the globalisation of production to social issues like precarisation and the polarization of income distribution or ecological challenges like climate change. It is these issues that will decide the future of PKE. We conclude that PKE offers an excellent starting point for macroeconomic analysis, but should develop its analysis further. In doing so, it should seek cooperation 
with other heterodox approaches in developing politically relevant problem-oriented alternatives to mainstream analyses.

The paper is structured as follows. Section 2 opens with a brief overview of important social and economic changes in the post-Fordist mode of development. We identify a neoliberal era and an era of enlightened neo-liberalism. Section 3 discusses the development of the mainstream during this time. Section 4 turns to the development of PKE and aims to identify achievements and weaknesses. Section 5 outlines a possible strategy for the future development of PKE. Finally, Section 6 concludes.

\section{Changes in the accumulation regime: From Fordism to neo-liberalism and enlightened neo-liberalism}

Given the interdependencies between the political economic development and the fate of economic theories we start with a brief overview over the most significant economic developments of the post-war period. The I950s to the mid I970s marked what has been called

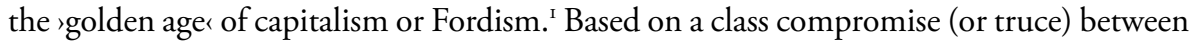
labour and capital, it was characterized by high growth and an active state. The international financial system was dominated by the Bretton Woods system of fixed exchange rates. Most states where characterised by an expanding public sector that procured the basic infrastructure of the economy and governments (in most developed countries) were committed to expansionary interventions in case of recessions. The welfare state emerged in many countries and provided a social safety net. This stable international and domestic background brought an unprecedented economic boom leading to high employment growth.

The period of rapid growth came to an end in the mid i970s. The prolonged period of full employment put the working class in a powerful position and led to a systematic upward-pressure on wages. Industrial conflict soared. In combination with increased international competition this led to what later came to be called 'profit squeezer (Glyn et al. 1990). Productivity growth slowed in part because of a slowdown in capital investment. The economic slowdown was further aggravated by the general hike in commodity prices and the oil price shocks. This external inflationary pressure triggered a wage-price spiral. Simultaneously the Bretton Woods system broke down under the pressure of persistent payment imbalances. This led to a stagflationary period and unemployment rates soared (by the times' standards) which was widely conceived as a crisis of the contemporary Keynesian policy framework. Political economists (Smithin 1996, Glyn 2004) have argued that with a militant labour movement and a surge in inflation (that had turned interest rates negative in the 1970s) industrial capital ended its truce with labour and realigned with financial capital. This new alliance abandoned Keynesian policies. The mid I970s marked the turn

I References include Aglietta (1976), Lipietz (1982), Boyer (1990) for the French Regulation School, Bowles et al. (1986) for the Social Structures of Accumulation Approach. For more recent discussion see the contributions in Marglin and Schor (1990) and Glyn (2006). 
to neo-liberal policies and the beginning of what we call the neo-liberal age. ${ }^{2}$ An imperturbable belief in the efficiency of free markets became the key element of the new catechism. At the core of the neo-liberal agenda has been a redefinition of the role of the government. The political shift occurred in several areas.

First, monetary policy acted as spearhead of the change of tides: by sharply increasing interest rates in the early I980s Central Banks accepted mass unemployment and the debt crisis in Latin America as the cost for reducing inflation. The abstinence from fiscal activities and independence of central banks in order to facilitate conservative monetary interventions was promoted and accomplished in many countries. Waves of privatisation and cutbacks of the public sector followed suit.

Second, strong labour unions where identified as an important cause of the stagflationary crisis and came under massive political pressure. Directly attacked by governments in the Anglo-Saxon countries, drained by persistent unemployment in (Western) Europe they lost organizational strength and political influence. The insistence on free markets justified cutbacks in the welfare state and the international opening of most economies - labelled globalisation - further increased the pressure on national working classes. The inability of unions to counteract these developments resulted in substantial redistribution of income from labour to capital, in a polarization of income distribution (even within the working class) and in a precarization of employment.

Third, domestic and international financial markets were gradually deregulated and liberalized. The belief in free markets led to a large-scale promotion of the ideas of free trade and international capital mobility. This led to fundamental changes in the financial landscape. At the international level capital flows were liberalized. Domestically changes in the financial framework gave rise to a rapid pace of financial innovation, eventually increasing the scope for speculation. Both developments strengthened the influence of the financial sector. Real interest rates rose well above the growth rates of real GDP. Financial ratios such as stock market capitalization, derivatives turnover or cross-border lending soared (Glyn 2006: 5I). Overall the income shares of financial capital increased considerably (Duménil/ Lévy 200I, Power et al. 2003). Moreover, the influence of financial investors on non-financial businesses has increased substantially under the so called shareholder value revolution (Lazonick/O'Sullivan 2000). These structural changes have been summarily called financialization; the structure of accumulation is now dominated by the financial sector (Stockhammer 2008a). A crucial side effect of this development has been that financial crises always intrinsic to capitalist economies (Kindleberger/Aliber 2005) - accelerated in both, frequency and impact. From the debt crisis of the early I980s, the EMS crisis of the early I990s to the South-East Asian and Latin American crises of the late I990s to the bursting of the dot.com bubble of early 2000 in the USA to the present crisis emanating from the

2 In regulationist terminology we would speak of neo-liberal mode of regulation and a financedominated accumulation regime (Stockhammer 2008a). See Glyn (2004) and Harvey (2005) for an extensive discussion of neo-liberalism. 
subprime mortgage sector - financial crises have been a reoccurring feature of finance-led capitalism.

In the early I990s neo-liberalism gave way to what we call enlightened neo-liberalism. This was a shift from free market ideology to a free market cum limited (and biased) state intervention. This more pragmatic approach incorporated interventions to address some market failures. While neo-liberalism (as in Friedman and Hayek) was an outright attack on the state and the claim that free markets would take care of themselves, enlightened neoliberalism accepts a role for the government as long as it is temporary and consistent with market incentives. Implicitly it was recognized that markets need institutions and governments (World Bank 2002). The central bank is thought to actively intervene in cases of financial crises. Not by chance is today's chairman of the Fed an eminent scholar on the economics of the great depression and the popular Taylor rule recommends counter-cyclical monetary policy. However, in the long run only free markets would be desirable. In terms of labour market policies the emphasis shifted from an outright dismantling of the welfare state to restructuring the welfare state such as to guarantee that market incentives are operational. In Europe this approach has come under the heading of flexicurity (European Commission 2007, ETUC 2007). State intervention in enlightened liberalism has always been biased. First, there is class bias. While in case of a financial crisis state support has been coming quickly and substantially, in case of unemployment state activism was restrained at best. Second, there is a double standard for core and peripheral countries. While expansionary government policy was considered necessary in case of a financial crisis in the North, the free market catechism was forced upon the countries of the developing world (see the special issue of the JPKE on the Washington Consensus in 2004-05).

Whilst the labour movement has been substantially weakened and has so far proven unable to effectively counter neo-liberalism, two waves of new social movements have ideologically challenged neo-liberalism: in the I980s, the environmental movement, the peace movement and the feminist movement and, in the I990s, the alter-mondialist movement. ${ }^{3}$ These largely operate aside conventional institutional forms of political participation. Compared to traditional labour movements this made it easier to develop a distinctly international dimension - an asset that hardly can be overstated in an age of international capital - but made it more difficult to exert direct influence. The fact that there has been no fusion of the labour movement and the new social movements is one of the causes for the weakness of the left.

The neo-liberal regime with deregulated finance has led to lingering social tension due to increasing social polarization and to a succession of financial crises. As the world goes trough financial and economic turmoil even the enlightened version of neo-liberalism is under pressure and increasingly questioned (Stiglitz 2008), even by former proponents (Wolf 2008). This in all likelihood will have some feedback on the dominant aca-

3 We use this term rather than ranti-globalization movement cause most of these movements criticize neo-liberal globalization and advocate a different, solidaristic kind of globalization. 
demic theories. To what extent this will benefit PKE is open. We do not intend to imply that the present crisis (or any of the ones that will inevitably follow in a deregulated financial regime) will bring about a (post-) Keynesian renaissance in academia, but it does create ideological discord and confusion within the mainstream and thus create opportunities of heterodox economists.

\section{The mainstream: Plus ça change...}

It has never been straightforward to define the mainstream. In order for the mainstream to be convincing it has to be broad enough to allow for debates. It cannot be completely homogenous but has to allow for conflicting views. Rather than identifying the mainstream with a particular theory, we define it as a common ground for debate (that excludes some arguments or theories). ${ }^{4}$ Let us circumscribe the mainstream institutionally with respect to two dimensions: what is published in the leading journals (or by economists at leading research institutions) and what leading economic policy institutions and governments use as theoretical foundation for their policies. The latter dimension is important because it highlights that mainstream economics is not a purely academic affair. It also will become obvious that there is substantial disagreement within the mainstream and there will be inner rings (where these dimensions overlap) and outer rings of the mainstream. Clearly, there can be dissent within the mainstream. We will highlight some changes over time and address the issue of what the mainstream is with respect to micro, macro and policy.

Let us thus begin by reviewing the post-war mainstream, that is, the neo-Classical-Keynesian synthesis (called »Bastard Keynesianism« by Joan Robinson). Its grand achievement was to maintain and reformulate the neo-Classical research program while giving room for some Keynesian arguments. The neo-Classical Keynesian synthesis had three important features. First, there was an uneasy split - one is tempted to say schizophrenia - between microeconomics and macroeconomics. While microeconomics was the world of rational behaviour, utility functions, optimizing behaviour and clearing markets (short, based on first principles), macroeconomics for large parts more pragmatically aimed at `realism ten taking social groups (rather than individuals) as starting point. Behavioural functions were intended to be realistic (plausible in an inductive sense) and non-clearing markets (in particular labour markets) were taken for granted. To be sure, there was no lack of tension between microeconomics and macroeconomics, which in turn fuelled research. A second feature is closely related to this schizophrenia: a sharp distinction between the short run and the long run (in particular in macroeconomics). This allowed leading economists (such

4 This is not intended to empty the term mainstream of its ideological content, but merely to dissociate from particular theories. While Monetarism would qualify as mainstream in the early I980s, by the mid I990s both New Keynesianism and Real Business Cycle Theory can be regarded as mainstream. The mainstream does have an ideological core: the belief that flexible markets will in the long run generate optimal outcomes. 
as Samuelson or Solow) to be Keynesian (in the short run) as well as neo-Classical (in the long run). Thirdly, in economic policy the mainstream was post-liberal (the term embedded liberalism has been coined for the post-war system): important parts of the economy were heavily shaped by state intervention, in particular the welfare state cushioned the market mechanism and financial markets were strongly regulated. Countercyclical policy was part of the policy agenda (Glyn 2006).

In the course of the I970s and 8os substantial changes occurred in all three fields: policy, macro and micro. The shift in economic policy has already been discussed in the Section 2. The break in macroeconomics was a conspicuous one, which ended with a redefinition of how macroeconomics had to be done - there had to be microfoundations. The neo-Classical attack took several forms (a rediscovery of Hayek, Monetarism, New Classical Economics, Real Business Cycle theory) and succeeded in establishing that in macroeconomics behavioural functions had to be derived from , first principles`, i.e. behavioural functions had to be derived from individual optimizing behaviour.

Eventually there was a reformulation of Bastard Keynesianism: New Keynesianism. It accepted the dogma of microfoundations and, by introducing transaction costs, seeked to generate pseudo-keynesian results. It is a resurrection of the synthesis but more thoroughly grounded in neo-Classical principles than the old version. It deviates from the neo-Classical research program: non-clearing markets are frequent (in the short run). New Keynesianism has become a powerful applied research program that informs policy making: from the NAIRU theory to business cycle theory. New Keynesian, in particular in the form of the so-called New Consensus Model (NCM), can now be considered mainstream with respect to macroeconomic policy making and is providing the theoretical basis for enlightened neo-liberalism. ${ }^{5}$ However in academia and in the leading journals, New Classicals are well and alive. ${ }^{6}$

The break in microeconomics was more of a shift (or a growth of niches) than a break. At the same time that New Classicals were resurrecting neo-Classical macroeconomics it became increasingly acceptable to transcend the neo-Classical research program in microeconomics itself. Colander et al. (2004) define the neo-Classical research program as the holy trinity of rationality, greed and equilibrium. Each of these has been questioned. First, a powerful literature emerged demonstrating that under asymmetric information (and ra-

5 Two examples will illustrate this point. First, after the South-East Asian financial crisis there was a short debate on the appropriate economic policies, in particular with respect to the IMF. The main proponents, Stanley Fischer (the IMF's chief economist) on the one hand and Joseph Stiglitz (the resigned chief economist of the World Bank) on the other hand are both leading New Keynesians. Second, the debate on European unemployment is analytically framed within the NAIRU model, again a New Keynesian model. According to the preference of the author it can be used to argue that monetary policy has been too tight (Ball 1999) or that rigid labor market institutions are to blame (IMF 2003, Nickell et al. 2005).

6 Basically no central bank is using a RBC model of the economy. In this sense they are all New Keynesians now. However in the form of DGSE models the RBC models sneak in again in policy making. 
tional behaviour) markets will typically not clear (Akerlof 1970, Stiglitz 1987). The implications of this approach are profound theoretically but ambiguous politically. Unlike the transaction costs of New Keynesian macro, information asymmetries do not disappear in the long run. Competitive equilibrium will not be pareto efficient and the First Welfare Theorem does not hold (Stiglitz 1994). Unlike the old Keynesian argument about the lack of effective demand, however, there usually is no quick fix (in terms of government policy) for the inefficiencies.

Second, there has been a growing empirical literature demonstrating that people do in many circumstances not behave rationally and that they often do not behave selfishly. Slowly experimental economics was born. People were shown to be sensitive to irrelevant details (framing), they include irrelevant information (anchoring) etc. and they happily cooperate in prisoners dilemma experiments. ${ }^{7}$

Representatives of both streams have received the highest honours of the profession: the Nobel Prize and a publication in the AER. They are thus part of the academic mainstream while they have strong post-Walrasian elements. Unfortunately the vice versa does not hold here. While (some) post-Walrasian economists (or arguments) clearly have become mainstream, it is much less clear whether the mainstream of microeconomics has become post-Walrasian.

Microeconomics has become a much more diverse field. Arguments can be made now, that only two decades ago would have been frowned upon and dismissed as irrelevant or, worse, sociological. ${ }^{8}$ Institutionally, however, the mainstream has become more rather than less exclusive. The high degree of formalization of economics is probably one of the most important barriers for heterodox economists (Lawson 2006). But many heterodox papers are formal. A frequent experience of heterodox economists is that their papers are rejected by mainstream journals without even being sent out to referees. The establishment of journal ratings and their use in tenure and hiring decisions is stifling innovation (Frey 2003) and has made it a lot harder for heterodox economists to get their work recognized. And there is a complex intermingling of politics and exclusionary mainstream: There are some theorems that are considered deep truths - for example that free trade is a good thing ${ }^{9}$ and

7 Useful overviews include Bowles and Gintis (2000) and Fehr and Fischbacher (2002).

8 Colander et al. claim that the "holy trinity of rationality, greed, and equilibrium is in the process of being replaced with a new orthodoxy, which can be described as an approach based on a holy trinity of purposeful behaviour, enlightened self-interest, and sustainability« (Colander et al 2004: VIII), but offer little evidence for this. Their discussion is based on "a list of interviewees who were working within this broader mainstream" (Colander et al 2004: VIII). While these are certainly "cutting edge economists " as the subtitle of the book reads, it is not obvious in what sense these scholars represent the mainstream. No serious attempt is made to evaluate the reactions of more orthodox parts of the mainstream and their ability to defend orthodoxy. Moreover, the book is practically silent on macroeconomic issues.

9 Telling examples include a comparison of Krugman's textbook on international trade and his academic writings, Samuelson's (2005) reply to the reactions on his $2004 \mathrm{JEP}$ paper or Blanchard's academic writings and his New School presentation. 
that minimum wages are bad for employment - that can only be questioned at the cost of potential loss of reputation despite the fact that there is a substantial literature questioning the theorems. ${ }^{\text {IO }}$

Economic policy is not only influenced by economic theories, but also by political interests. One should thus not be surprised that economic policy at times conflicts with ideology. Nonetheless one can discern some pattern. In the I980s neo-liberals were ruling the show. Since the mid I990s one does notice some less dogmatic positions in the international organizations and the USA (but less so in Europe). Most stark is the double standard about the trust in financial liberalization. While deregulation and liberalization and an anti-inflationary response in case of financial crisis were forcefully preached to (and often forced upon by the IMF) the developing world, the policy reaction to the financial crises in the USA seemed to be little inhibited by trust in the self-healing abilities of the market system that neo-liberalism had been preaching for decades. Whether this feeds back into theorizing or not remains to be seen. In terms of analysis there have been some signs that important institutions were getting more open-minded albeit within narrowly prescribed borders (OECD 2006, World Bank 2006).

Overall the mainstream appears as a contradictory, if nonetheless repressive creature. While theoretically the mainstream has become more open, institutionally it has become more closed: heterodox economics is largely excluded from mainstream journals and institutions. In the field of macroeconomics New Keynesians appeared as a remake of the neoClassical Keynesian synthesis cum microfoundations. In the short run demand matters, in the long run not. The major difference to the old synthesis is that today microfoundations (based on optimizing behaviour) are accepted as an essential ingredient whereas for the old synthesis macro was a separate field. Ironically, there is a substantial difference between microeconomics as a field of research and micro-foundations of macroeconomics. In microeconomics, experimental economics and behavioural economics questions about the very foundations of homo economics are discussed (within the mainstream), while on the other hand modern macroeconomics takes optimizing behaviour (and the need for neo-Classical microfoundations) for granted.

\section{The status quo of post-Keynesian economics}

Institutionally the history of PKE outside of the mainstream is relatively young. The first generation of PKs (Kahn, Kaldor, Robinson, Sraffa) - that started to evolve in the heydays of Keynesian policies and the neo-Classical Keynesian synthesis - was based in top universities and published in leading journals. Their research program initially focused on developing Keynes' theory of effective demand into a theory of the long run. This led to a focus on theories of growth and distribution (Kaldor 1956, Robinson 1956) that was supplement-

Io David Card reports staying away from the minimum wage topic after experiencing intense peer pressure. (Hayes 2007). 
ed by monetary and financial aspects by an American line of economists (Weintraub 1959, Minsky 1957). These economists were deviants in a theoretical sense but as the capital controversies show they were still taken seriously by the mainstream (Levhari/Samuelson I966, Solow 1975, Harcourt 1969).

The issues of distribution and growth have remained prominent in the PK discussion ever since, particularly in the form of Kaleckian models. The foundation of these models is a class-based analysis of the growth process. They usually entail capacity under-utilization and mark-up pricing (Dutt 1984). The modern appearance of these models has an exogenously determined profit margin (via mark-up pricing) which implies exogenously determined real wages. Further these models commonly exhibit the paradox of thrift and the paradox of cost. The paradox of thrift results out of the assumption that capitalists save more than workers. Since the economy grows until investment equilibrates savings an exogenous redistribution of income towards workers increases growth. Via accelerated growth thus a reduction in the aggregate propensity to save leads to an increase in aggregate savings. The paradox of costs on the other hand refers to the fact that an increase in aggregate costs (i.e. wages) leads to an increase in economic activity and thus to an increase in profit. In extended versions different accumulation regimes are possible (Blecker 1989, Marglin/Badhuri 1990), that is growth may be profit led or wage led. The Kaleckian model further is the basis of the rich $\mathrm{PK}$ analysis of inflation. In this literature inflation is regarded as a cost-push phenomenon or a result of an unresolved distributional conflict (Hein/Stockhammer 2007).

The PK focus on monetary issues was in part a reaction to the rise of monetarism. Long before it was (implicitly) acknowledged by the mainstream, PKs insisted on the endogenous nature of the money supply (Kaldor 1982). This insight led to a focus on the functioning of the banking sector which in the late 1980 os triggered a massive debate about the particular shape of the money supply function. The PK views on endogenous money largely fell into two camps. The horizontalist analysis started with the observation that loans create deposits which at the time was an exact inversion of standard wisdom. Since thus, the banking sector was not constrained quantitatively they concluded that the money supply is solely determined by the creditworthy demand for credit; that is the money supply is demand determined (Moore 1989). Structuralists on the other hand maintained that the asset and liability management of banks matters. From this point of view the money supply is in principle endogenous to the banking system. However, the larger the sum of outstanding credit becomes and the higher the average risk of credits becomes the more difficulties arise for banks to maintain the reserve requirements. Consequently, there exists some systematic relationship between the amount of outstanding credit and the interest rate (Pollin I99I, Palley 1996). This discussion yielded a deep understanding of the functioning of the banking industry. Despite the fact that it is still ongoing there seems to be some convergence of the respective positions (Fontana 2004).

Based on this broad theoretical background PK authors recently started to develop a well-grounded critique of the NCM (Arestis/Sawyer 2004). An obvious critique originating from the PK understanding of banking is the lack of an analysis of the banking sector. There is some progress compared to earlier neo-Classical models in that the money supply 
is endogenous to the model but it is simply determined as a residual without considering the role of the banking sector. This is particularly surprising given the fact that NCM implicates a massive focus on monetary policy by its insistence on inflation targeting. From a $\mathrm{PK}$ point of view this insistence on inflation targeting however focuses too strongly on a demand-pull type of inflation (see special issue of the JPKE 2006). Finally, the vertical longrun Phillips Curve is particularly problematic from a PK perspective (Arestis/Sawyer 2004). Under such a framework long-run effects of effective demand simply do not exist.

Related to this literature is a recent stream of the literature which is concerned with policy issues and empirical research. In Europe one major objective of this literature has been to critically evaluate the economic design of the European Union and to formulate sensible alternatives. Obvious and important fields of intervention for these contributions are the lack of fiscal coordination in Europe and the contemporaneous monetary policy design. This implies a sound critique of the Stability and Growth Pact and propositions of alternative policies as concerns tax and wage policy coordination (Arestis et al. 200I). The discussion hereby is particularly led in light of the lacking convergence within the European Union (Hein/Truger 2005) and is concerned with the adjustment of labour market institutions and wage policies (Stockhammer 2008b). A further field is the critical evaluation of the monetary policy of the ECB. The understanding of the stratification of capitalist societies hereby allows PKs to recognize that the one-sided focus on price stability mainly serves the interests of specific interest groups.

PKs thus are actively and continuously making important contributions to the understanding of the macro economy. Their contributions are even more remarkable when the hostile environment under which they had to be developed is taken into account. PKs were able to reach a critical mass at some research institutions and have established specialized journals. However, their existence is heavily contested and they are widely ignored by the mainstream. This is a major difference to the times of the capital controversies when it was still possible for PK authors to trigger a debate with the mainstream. Today only few PKs are able to publish in mainstream journals (e.g. Arestis et al. 200I), most survive by establishing niches. This of courses reduces their impact as regards quantity of citations and similar criteria which makes it harder for them when it comes to evaluations and rankings.

After the Cambridge Controversies PKs were effectively excluded from the mainstream and have been unable to exploit the contradictions and upheavals within mainstream economics. In particular the innovative fringe of mainstream microeconomics seems to be unaware of PKE (and at times even of macroeconomics as a distinct field). Worse, this neglect of PK ideas occurs at the same time as some long standing arguments of PK theory are usurped by the mainstream. The idea of endogenous money has been tacitly incorporated into models of NCM where the money stock is determined as a residual in these models. Further it can be argued that the idea of conflict inflation is incorporated in the New Keynesian NAIRU narrative of the short run (Stockhammer 2008c). Also the notion of hysteresis incorporates PK ideas of the path-dependency of the economic growth process. All of this happens without acknowledging of the widely available pioneering PK literature on those subjects. On the other hand (and partly out of a reaction to their contested situation) PKs 
indeed tend to be highly critical of the mainstream. The potential scope of fruitful interaction between PK and the innovative edge of mainstream microeconomics remains largely unexplored and there are few attempts to communicate from the PK side (such as the special issue of Journal of Economic Psychology 2004).

If the yardstick for the evaluation of the relevance of an economic theory is its relevance for socially important issues, PKs have to take some blame for certain shortcomings. PKE has been focused on a rather reduced set of key concepts initiated by Keynes. Having their own virtue this however left certain white points on the PK map of the real world:

I. There is a strange disparity between the relevance of financial crises in Keynes and the important contributions of Minsky (1982, 1986) and his followers and general PK macro-models. For example Rochon (1999) and Hein (2008) are two excellent recent treatments of PK monetary theory that do not discuss financial instability as a possible effect of endogenous money. Financial instability still appears as an anomaly in the standard PK macro-models. ${ }^{\text {II }}$

2. Apart from the Kaldor-Verdoon law and certain important exceptions (Arestis/Sawyer 2005, Dutt 2006, Bhaduri 2006) analyses related to the supply side hardly appear in the PK literature. Overall, the supply side thus is largely neglected by PKs. This makes it difficult to consider aspects such as ICT or the »knowledge society«. Moreover, the effects of the transnationalization of large corporations and the restructuring of value chains have not received much attention of PKs.

3. Despite the prominence of the effects of distribution in PK growth models there is hardly any analysis of the determinants of distribution. Such crucial factors as union density, the real interest rate or the mark-up enter PK models as exogenous variables. There is hardly any organic PK research on how strong the impact of different institutional factors (such as union density, central bank behaviour ...) on the mark-up is or what determines participation in worker's organizations.

4. Closely related to 3 there exists no PK theory of the state and no systematic analysis of the Political Economy. A benevolent public administrator is still implied in many PK models. ${ }^{12}$ Keynes's path-breaking analysis of effective demand established the basis for full-employment oriented economic policy. Seventy years later economists still essentially propose the same kind of pre-keynesian macroeconomic policies. PKs lack an explanation of the stronghold that orthodox economics has on the profession and on the state. Kalecki (1943) had highlighted the political contradiction of full employ-

II This is not to say that no analysis in this important field occurs (see e.g. Skott 1994 and 1995 and the work at the Levy Institute). Our point though is that this analysis occurs alongside the major analytical tasks and is only rarely integrated.

I2 Keynes himself was convinced that his policy recommendations could be implemented by means of persuasion and that the lack of their implementation was mainly due to the administration not having understood them properly (Cardim de Carvalho 2009). However, he overlooked the possibility that some social groups might oppose policies overall lead to superior outcomes (in terms of employment and output) because it worsens their relative or absolute position. 
ment policies, but this issue has not been addressed systematically by PKs. There is no systematic analysis of the motives and impact of political interest groups. Of course this is a critique that universally applies to economics.

5. Finally, PKE seems to offer little to evaluate such developments as precarisation or flexicurity from a social perspective. PKE has little to say on issues by which some important groups of modern societies are concerned.

\section{How to move forward}

PKE shares its defensive position with most heterodox approaches. Lawson (2006) has argued that methodology is the unifying thread for heterodox economists. This view implies that heterodox economists by definition cannot enter a discussion with the mainstream as they speak a different language - they analyse the economy as an open system rather than as a closed system. More specifically, Lavoie (2006) points out that there are similarities between various heterodox positions on crucial issues like rationality and an organicistic approach to society.

This is the background for the ongoing debate on the future of PKE. Two important contributions have recently argued that the key to the future is entering a dialogue with mainstream economics.

"The way forward is for PKE to engage in a more constructive dialogue with mainstream economics with the objective of encompassing relevant neo-Classical models within a more general framework that incorporates PK alternatives.« (Fontana/ Gerrard 2006: 72)

A similar point has been made by Colander et al. in a series of publications (Colander et al. 2004, 2006 and $2007-8$ ). They argue that heterodox economists should not dwell on the unfairness of being excluded by the mainstream but try to express their arguments in ways comprehensible to mainstream economists. All that would be required is a formalization of the arguments, the cutting edge of the mainstream would be eager to listen (Colander et al. 2004). ${ }^{13}$ Colander et al. exclusively refer to microeconomists. However, modern macroeconomics has been largely left untouched in the upheavals of modern microeconomics. There are few (and isolated) attempts to integrate non-standard microfoundations into macroeconomic models (Akerlof 2007 being a rare exception). The overriding concern of PKE however is with macroeconomics. ${ }^{14}$ The restricted development of modern macroeco-

I3 Much to their credit, it has to be said that Colander and co-authors put their energy where their mouth is. In particular, Barkely Rosser (one of the co-authors of Colander et al. 2004) plays an important role as a communicator between this edge of more innovative mainstream and heterodox authors in his role as editor of the Journal of Economic Behavior and Organization.

I4 Fred Lee has, correctly, pointed out that this statement does not do justice to those PK economists who have contributed to microeconomic theory like Alfred Eichner, Nina Shapiro, Paul Down- 
nomics and the fact that PKs have been largely ignored even in the few fields where the both sides have converged (King 2008: 2I) though make the existence of "within mainstream" improbable. This is aggravated by the fact that PK (Heterodox) authors are often discriminated by the mainstream which in most economics departments enjoys a power position (Dequech $2007-8$ ).

Our contribution to this debate is not a novel position on whether it is desirable to enter a dialogue with the mainstream or not. ${ }^{\text {Is }}$ Rather our point is that the issue of entering into a dialogue is a secondary one for the future of PKE. Whether PKs put more effort into entering a dialogue with the mainstream will make little difference, simply because there is little indication that the core of the mainstream is interested in this dialogue. In fact it typically does not even recognize the existence of PKE (or most other heterodox streams).

Despite the fact that we believe that PKE provides an excellent basis for economic analysis and in many ways provides deeper insights than the mainstream we think that the focus on the relation to the mainstream is misplaced. Rather PKE should look at the real world (to identify pressing problems), look at themselves (to identify shortcomings in their analysis) and at other heterodox streams (to find specific areas of complementarities).

Our first recommendation is rather basic: be politically relevant.$^{16}$ It is hard to overstate the importance of this. It is crucial to develop analyses and policy suggestions for new social and economic problems and communicate them within the profession and to a broader public. This is crucial to attract new students as well as the attention of the economic policy institutions. While we have little hope of displacing the mainstream in the short run, we doubt that this hegemony will go unchallenged in the future. But change is unlikely to come from within the profession. Economics will be changed by forces from the outside. It's the economy rather than economics that will call for change. The finance-dominated accumulation regime is prone to crises due to unregulated financial markets and the neoliberal mode of regulation is leading to a polarization of income distribution and a precarization of employment relations.

This does not mean that a systemic crisis or a revolutionary upheaval is around the corner. But it does mean that orthodox economics and the neo-liberal mode of development will loose legitimacy. As already apparent in the handling of the present financial crisis, neoliberal principles are pragmatically jettisoned to save financial institutions. Thus, why should we not also ignore them in order to help the unemployed? Different fields of economics will

ward and himself.

I5 The main benefit of a dialogue would be that PKE might be noticed by the innovative fringes of the mainstream. The value of Colander et al.'s contribution is - in our view - not their conclusion, but that they highlight many of the interesting and challenging developments at these fringes.

I6 This is not intended as the reinvention of the wheel. Indeed, many PKs are well aware of this basic imperative. In particular the Levy Institute, the Political Economy Research Institute (PERI), the annual conference of (German) Research Network Macroeconomics and Macroeconomic Policies already have a policy-oriented focus as do many special issues of the JPKE. Paul Davidson and Henry Liu have initiated an open letter regarding the reform of the financial markets (Davidson/Liu 2008) and the list could well be extended. 
be differently affected by such debates, but macroeconomics will certainly be at the centre of many debates. This will be an opportunity for PKE to proof its usefulness. But it also poses challenges for PKE. The present crisis will not be a re-run of the I930s. Governments as well as New Keynesian economists are much more pragmatic than their counterparts 80 years ago. At the same time the social movements pressing for change are much more heterogeneous as are the social tensions out of which they have grown. Nor is there a strong political movement (as the socialist movement of the 1920s) pushing for fundamental societal change. In other words, it is not clear to what extent PKE will be able to benefit from the repercussions that the present financial crisis will have on economics. Developing an analysis (and policy suggestions) for present problems will force PKs not only to develop further their theory of financial crisis but also to address issues that they have had little to say about as of yet: globalization, the working poor, atypical employment relations.

While the medium run may offer more room for debates, in the present and the near future, the situation of PK has accurately been described as that of an embattled minority (King 2002). Among the most pressing problems are the marginalization in academia via research assessments and journal ratings. The formation of heterodox economics as well as (possibly) the consolidation of dissenting views at the fringes of the mainstream offers new chances.

Our second recommendation is thus that PKs seek to cooperate institutionally with other heterodox approaches and non-orthodox streams. PKs alone simply do not have the critical mass to press for change in economics. The aim of this cooperation is twofold. The first is the fight for a pluralistic economics in general. Many of the heterodox umbrella organisations (such as EAEPE, AHE or ICAPE) have been founded to provide a friendly climate for the discussion of otherwise suppressed research. They should now move forward and try to actively defend heterodox research from (further) marginalization. More pluralism in economics involves many issues, one of the strategically important among them is the fight for more inclusive journal ratings and evaluation mechanisms. For this, large associations are needed as lobbying institutions. Second, these institutions should actively encourage research projects transcending the existing camps among the different streams of heterodox economics. However, a sober assessment would probably conclude that the heterodox umbrella organizations have so far not been very successful in this dimension. But it is a vital issue if heterodoxy is to effectively challenge the mainstream of economics.

The third recommendation is that the research agenda of PK requires expansion in several directions. As elaborated in Section 3, PKE has in several important aspects kept too closely to its original research program and shows crucial gaps in its analysis. PKE, in other words, should become more Post and less Keynesian - not in term of the analysis, but in terms of the questions asked. Changes in the economy and developments in mainstream economics as well as in other heterodox approach have made many of these gaps apparent. Some examples will illustrate our case. First, consider the role of institutions. While it may not be very surprising that institutionalists have more to say about institutions in general than $\mathrm{PK}$, it is ironic that mainstream economics now often makes a much more elaborated empirical attempt to include the effects of institutions on economic growth than 
PKE (even if these attempts in practice often degenerate into an additional dummy variable in econometric analysis). This is in spite of the fact that PKs have long argued (certainly much longer than mainstream growth theory) that institutions matter for growth. Second, there is a broad range of recent social and economic phenomena that PKs have had little to say about: ICT, globalization, precarisation and environmental destruction. Many of these changes are either "too supply-side" or "too micro" for PKs. While some of these issues may seem remote from PK theory, others are close to home, but have been ignored. For example, there is next to no discussion of environmental degradation in PK growth theory. Third, PKE has also failed to elaborate a theory of the state and the social groups that influence government behaviour. Essentially PKE has no answer to the question, why pre-keynesian economic policies persist. In Keynes' times it was easy to argue, that they didn't know better. Neo-liberalism, however, seems to be based on a deliberate decision not to use Keynesian policies. Enlightened neo-liberalism uses government policies selectively and in a class-biased way.

In all these areas there should be obvious potential gains from cooperation between PKs and other heterodox positions. Institutional and evolutionary economics have elaborate theories of institutions, Ecological Economists have done a lot to highlight the detrimental effects of growth, Marxists have developed rich theories of class and the state. We are not advocating a grand heterodox synthesis, but problem-specific heterodox synthesis approaches. ${ }^{17}$ Take real-world problems and analyse them by making use of different heterodox approaches. PKE is plainly not sufficient to do justice to many of today's social and economic problems.

\section{Conclusion}

The debate on the future of PKE has focused on PKE's relation to the mainstream. This has served to highlight the rich and contradictory developments within the mainstream. There is an intimate, if complex, link between the mainstream in academia and in economic policy. A version of New Keynesian theory has been identified as the core of the mainstream, that is consistent with enlightened neo-liberalism, i.e. accepting a role for the state in the short run while establishing a competitive equilibrium as the key long run reference point. In academia the mainstream has become more open internally in the past two decades with the development of post-Walrasian ideas in microeconomics (in particular where they have little relation to or effect on economic policy). At the same time the fences around mainstream economics have become high by means of excessive formalization, discriminatory journal ratings and (less subtly) by blatant exclusion.

I7 A grand unifying heterodox synthesis may be the outcome of such cooperative project, but it is far from clear whether different heterodox approaches are consistent. However, this does not preclude a problem-oriented cooperation among heterodox approaches. 
We have argued that this focus on the relation to mainstream economics is misplaced. While the dialogue with the mainstream may be desirable, the key questions for PKs lie elsewhere. First, PKE has to be relevant in explaining real-world problems. The neo-liberal mode of development delivers enough of them as the present financial crisis demonstrates. This may come with its own dilemmas, e.g. academic credibility vs. political applicability, but it will raise more interesting questions than trying to reformulate PK models such that they are easy to understand for mainstream economists (if they care to listen). Second, institutionally, PK should strengthen their ties with other heterodox economists to defend space for pluralism in the profession. Thirdly, PKE should fill the gaps in its theory. Many of the present-day social and economic problems are not sufficiently addressed in PK analysis. Doing so will take PKs beyond PKE, they should do so by cooperating with other heterodox streams.

\section{References}

Aglietta, M. (1979): A Theory of Capitalist Regulation. The US Experience, London: Verso.

Akerlof, G. (1970): The market for lemons, in: Quarterly Journal of Economics, 84(3), $488-500$.

Akerlof, G. (2007): The missing motivation in macroeconomics, in: American Economic Review, 97(I), 5- 36 .

Arestis, P., Demetriades, P., Luintel, K. (200I): Financial development and economic growth: The role of stock markets, in: Journal of Money, Credit and Banking, February, 33(I), I6 - 4I.

Arestis, P., McCauley, C., Sawyer, M. (200I): An alternative stability pact for the European Union, in: Cambridge Journal of Economics, 25, $113-130$.

Arestis, P., Sawyer, M. (2004): Re-examining Monetary and Fiscal Policy for the Twenty-first Century, Cheltenham: Edward Elgar.

Arestis, P., Sawyer, M. (2005): Aggregate demand, conflict and capacity in the inflationary process, in: Cambridge Journal of Economics, 29(6), 956 - 974.

Ball, L. (1999): Aggregate demand and long-run unemployment, in: Brooking Papers on Economic Activity, 2: $189-236$

Bhaduri, A. (2006): Endogenous economic growth: A new approach, in: Cambridge Journal of Economics, 30(I), $69-83$.

Blecker, R. (1989): International competition, income distribution and economic growth, in: Cambridge Journal of Economics, $\mathrm{I} 3,395$ - 412.

Bowles, S., Gintis, H. (2000): Walrasian economics in retrospect, in: Quarterly Journal of Economics, II5(4), I4II - I439.

Bowles, S., Gordon, D., Weisskopf, T. (1986): Power and profits: The social structure of accumulation and the profitability of the postwar US economy, in: Review of Radical Political Economics, I\&2, I32 - I67.

Boyer, R. (1990): The Regulation School: A Critical Introduction, New York: Columbia University Press. 
Cardim de Carvalho, F. (2009): Keynes and the reform of the capitalist social order, in: Journal of Post Keynesian Economics, 3I(2), I9I - 2II.

Colander, D., Holt, R., Rosser, B. (2004): The changing face of mainstream economics, in: Review of Political Economy, I6(4), 485- 499.

Colander, D., Holt, R., Rosser, B. (2006): The Changing Face of Mainstream Economics - Conversations with Cutting Edge Economists, Michigan: University of Michigan Press.

Colander, D., Holt, R., Rosser, J. (2007 - 8): Live and dead issues in the methodology of economics, in: Journal of Post Keynesian Economics, $3 \mathrm{O}(2), 303-3 \mathrm{I} 2$.

Davidson, P., Liu, H. (2008): Open letter: The way forward, in: Asia Times, Nov. 8.

Dequech, D. (2007 - 8): Neoclassical, mainstream, orthodox, and heterodox economics, in: Journal of Post Keynesian Economics, 30(2), 279- 302.

Duménil, G, Lévy, D. (200I): Costs and benefits of Neoliberalism: A class analysis, in: Review of International Political Economy, 8 (4), 578 - 607.

Dutt, A. (1984): Stagnation, income distribution and monopoly power, in: Cambridge Journal of Economics, 8, 25-40.

Dutt, A. (2005): On Post Walrasian economics, macroeconomic policy, and heterodox economics, in: International Journal of Political Economy, 33(2), 47-67.

Dutt, A., (2006): Aggregate demand, aggregate supply and economic growth, in: International Review of Applied Economics, 20(3), $319-336$.

European Commission (2007): Towards Common Principles of Flexicurity: More and better Jobs through Flexibility and Security, Luxembourg: European Commission.

European Trade Union Confederation [ETUC] (2007): Commission's communication on »Towards Common Principles of Flexicurity: More and Better Jobs through Flexibility and Security«, ETUC's position adopted by the ETUC Executive Committee of 17 - I8 October 2007, URL: http://www.etuc.org/a/4233.

Fehr, E., Fischbacher, U. (2002): Why social preferences matter - The impact of non-selfish motives on competition, cooperation and incentives, in: Economic Journal, II2, CI - C33.

Fontana, G. (2004): Rethinking endogenous money: A constructive interpretation of the debate between horizontalists and structuralists, in: Metroeconomica, 55(4), $367-385$.

Fontana, G., Gerrard, B. (2006): The future of Post Keynesian economics, in: Banca Nazionale del Lavoro Quaterly Review, 59(236), 49-80.

Frey, B. (2003): Publishing as prostitution? - Choosing between one's own ideas and academic success, in: Public Choice, II6(I-2), $205-223$.

Glyn, A. (2004): Capitalism Unleashed: Finance, Globalization and Welfare, Oxford: Oxford University Press.

Glyn, A., Hughes, A., Lipietz, A., Sing, A. (1990): The rise and fall of the Golden Age, in: Marglin, S., Schor, J. (eds.), The Golden Age of Capitalism, Oxford: Clarendon Press, $39-\mathrm{I} 25$.

Harcourt, G. (1969): Some Cambridge controversies in the theory of capital, in: Journal of Economic Literature, $7(2), 369-405$.

Harvey, D. (2005): A short History of neo-liberalism, Oxford: Oxford University Press.

Hayes, C. (2007): Hip heterodoxy, in: The Nation, June Ir. 
Hein, E. (2008): Money Distribution Conflict and Capital Accumulation. Contributions to ,Monetary Analysis‘, Basingstoke: Palgrave Macmillan.

Hein, E., Stockhammer, E. (2007): Macroeconomic policy mix, employment and inflation in a Post Keynesian alternative to the new consensus model, Department of Economics Working Paper Series, No. IIo, Vienna.

Hein, E., Truger, A. (2005): European Monetary Union: Nominal convergence, real divergence and slow growth?, in: Structural Change and Economic Dynamics, 16, 7 - 33.

IMF (2003): Unemployment and labor market institutions: Why reforms pay off, Chapter IV of World Economic Outlook April 2003.

Kaldor, N. (1956): Alternative theories of distribution, in: Review of Economic Studies, 23(2), 83 - IOO.

Kaldor, N., (1982): The Scourge of Monetarism, Oxford: Oxford University Press.

Kalecki, M. (1943): Political aspects of full employment, in: Political Quarterly, XIV(4), 322 - 33I, reprinted in: Kalecki, M. (197I): Selected Essays on the Dynamics of the Capitalist Economy, Cambridge: Cambridge University Press.

King, J. (2002): A History of Post Keynesian Economics Since 1936, Cheltenham: Edward Elgar.

Kindleberger, C., Aliber, R. (2005): Manias, Panics and Crashes, Basingstoke: Palgrave Macmillan.

King, J. (2008): Heterodox macroeconomics: What exactly are we against?, in: Wray, R. (ed.), Keynes and Macroeconomics After 70 Years, Cheltenham: Edward Elgar, 3 - I9.

Lavoie, M. (2006): Do heterodox theories have anything in common? A Post-Keynesian point of view, in: Intervention, $3(\mathrm{I}), 87-\mathrm{II} 2$.

Lawson, T. (2006): The nature of heterodox economics, in: Cambridge Journal of Economics, $30,483-505$.

Lawson, T. (2007): Methodological issues in the study of gender, in: Journal of International Economics Studies, 2I, I - 66.

Lazonick, W., O'Sullivan, M. (2000): Maximizing shareholder value: A new ideology for corporate governance, in: Economy and Society, 29(I), $13-35$.

Levhari, D., Samuelson, P. (1966): The nonswitching theorem is false, in: The Quarterly Journal of Economics, 80(4), 518 - 519 .

Lipietz A. (1985): The Enchanted Word, London: Verso.

Marglin, S., Badhuri, A. (1990): Profit squeeze and Keynesian theory, in: Marglin, S., Schor, J. (eds.), The Golden Age of Capitalism - Reinterpreting the Postwar Experience, Oxford: Clarendon Press, I53 - I86.

Marglin, S., Schor, J. (1990) (eds.): The Golden Age of Capitalism, Oxford: Clarendon Press.

Minsky, H. (1957). Monetary systems and accelerator models, in: American Economics Review, $47,859-883$.

Minsky, H. (1982): The financial instability hypothesis: Capitalist processes and the behavior of the economy, in: Kindleberger, C., Laffargue, J.-P. (eds.), Financial Crises: Theory, History and Policy, Cambridge: Cambridge University Press.

Minsky, H. (1986): Stabilizing an Unstable Economy, New Haven: Yale University Press. 
Moore, B. (1989): A simple model of bank intermediation, in: Journal of Post Keynesian Economics, I2(I), IO -28.

Nickell, S., Nunziata, L., Ochel, W. (2005): Unemployment in the OECD since the r960s: What do we know?, in: Economic Journal, I5, I - 27.

OECD (2006): Employment Outlook 2006, Paris: OECD.

Palley, T. (1996): Post Keynesian Economics: Debt, distribution and the macro economy, Basinstoke: Palgrave Macmillan.

Pollin, R. (I99I): Two theories of money supply endogeneity: Some empirical evidence, in: Journal of Post Keynesian Economics, $13(3), 366-398$.

Power, D., Epstein, G., Abrena, M. (2003): Trends in the rentier income share in OECD countries 1960 - 2000, PERI Working Paper 58a.

Robinson, J. (1956): The Accumulation of Capital, London: Macmillan.

Rochon, L.-P. (1999): Credit, Money and Production. An Alternative Post-Keynesian Approach, Cheltenham: Edward Elgar.

Samuelson, P. (2004): Where Ricardo and Mill rebut and confirm arguments of mainstream economists supporting globalization, in: Journal of Economic Perspectives, 18, 242 - 244 .

Smithin, J. (1996): Macroeconomic Policy and the Future of Capitalism: The Revenge of the Rentiers and the Threat to Prosperity, Cheltenham: Edward Elgar.

Solow, R. (1975): Brief comments, in: The Quarterly Journal of Economics, 89(I), 48 - 52.

Stiglitz, J. (1987): The causes and consequences of the dependence of quality on price, in: Journal of Economic Literature, 25, I - 48.

Stiglitz, J. (1994): Whither Socialism?, Cambridge, Mass.: MIT Press.

Stiglitz, J. (2008): The end of neo-liberalism, in: New Europe, July 2I.

Skott, P. (1994): On the modeling of systemic financial fragility, in: Dutt, A. (ed.): New Directions in Analytical Political Economy, Aldershot: Edward Elgar.

Skott, P. (1995). Financial innovation, deregulation, and Minsky cycles, in: Epstein, G., Gintis, H. (eds.), Macroeconomic Policy After the Conservative Era, Cambridge: Cambridge University Press.

Stockhammer, E. (2008a): Some stylized facts on the finance-dominated accumulation regime, in: Competition and Change, $\mathrm{I2}(2), \mathrm{1} 89-207$.

Stockhammer, E. (2008b): Wage moderation does not work, in: Review of Radical Political Economy, 39(3), 39I - 397 .

Stockhammer, E. (2008c): Is the NAIRU a Monetarist, New Keynesian, Post Keynesian or Marxist theory?, in: Metroeconomica, 59(4), 479 - 510.

Weintraub, S. (1959): A General Theory of the Price Level, Output, Income Distribution and Economic Growth, Westport: Greenwood Publishing.

Wolf, M. (2008): The rescue of Bear Stearns marks liberalisation's limit, in: Financial Times, March 25.

World Bank (2002): Building Institutions for Markets, World Development Report 2002, Washington, DC: Worldbank.

World Bank (2006): Equity and Development, World Development Report 2006, Washington, DC: Worldbank. 